\title{
Transatlantica
}

Revue d'études américaines. American Studies Journal

\section{Doctor Honoris Causa Acceptance Speech, University of Caen, 2007}

In Memoriam Michel Fabre

Henry Louis Gates Jr.

\section{OpenEdition}

Journals

\section{Édition électronique}

URL : https://journals.openedition.org/transatlantica/4251

DOI : 10.4000/transatlantica.4251

ISSN : 1765-2766

Éditeur

Association française d'Etudes Américaines (AFEA)

Référence électronique

Henry Louis Gates Jr., « Doctor Honoris Causa Acceptance Speech, University of Caen, 2007 »,

Transatlantica [En ligne], 1 | 2009, mis en ligne le 23 juin 2009, consulté le 17 septembre 2021. URL

http://journals.openedition.org/transatlantica/4251 ; DOI : https://doi.org/10.4000/transatlantica. 4251

Ce document a été généré automatiquement le 17 septembre 2021.

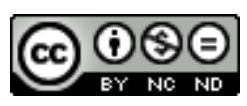

Transatlantica - Revue d'études américaines est mise à disposition selon les termes de la licence Creative Commons Attribution - Pas d'Utilisation Commerciale - Pas de Modification 4.0 International. 


\section{Doctor Honoris Causa Acceptance Speech, University of Caen, 2007}

In Memoriam Michel Fabre

Henry Louis Gates Jr.

1 It is with deep appreciation and humility that I accept this great honor, the Doctor Honoris Causa, from the historic and triumphant University of Caen. I regret that I cannot be with you in person to accept this degree, and thank my dear friend and colleague, Alice Mills, for saying a few words of thanks for me.

2 To be honored by an esteemed French university for the work that I have done in the field of African American literature goes far beyond what I would have imagined for myself in 1975, when I returned to the United States from graduate school in English Language and Literature at the University of Cambridge in England. I fled Cambridge, which, at that time cast African literature and even the great Nigerian playwright, Wole Soyinka, to the margins of the social sciences, for Yale University, my undergraduate institution and the home of Professor Charles T. Davis and his groundbreaking Program in Afro-American Studies. Mister Davis, as we called him, insisted that I undertake the study of black literature formally. In 1976, I enrolled in his course, "The Afro-American Literary Tradition," and it was in this class that I fell in love with African American literature.

3 Mister Davis often reminded my classmates and me that we were at the beginning of the formal study of this great literary tradition in the broader academy, which had only begun to appear in U.S. English Department and American Studies curricula in the late 1960s, and that we had the great fortune of being unburdened by a mountain of secondary sources through which we had to wade to establish our scholarly credentials. This was something of a curse, also, since there was scant critical tradition upon which to build our work, meaning that we would have to resurrect the texts of the tradition before explicating them, that we had to be meticulous literary historians as well as close and clever literary critics. We were to introduce, conserve, and challenge a rich and largely unstudied literary tradition. We were to commit ourselves to it, and I have never been more thankful that I accepted Mister Davis's challenge than I am today. 
4 My love and respect for Mister Davis led me to the work I do today, and for which you so greatly honor me. In doing this work on African American literature, I have had the great privilege of learning more about the larger world as well. One of my greatest teachers about the larger world was Michel Fabre, a cherished colleague and friend who left us too soon earlier this year. Michel Fabre knew more about the African American author Richard Wright than anyone else, and through his work on Wright and other African American expatriate writers, Michel taught me about "black Paris," that thriving artistic community that dates all the way back to 1840, in Michel's unmatched literary historical excavation of this community and this city. In a larger sense, Michel was one of the first scholars to show that African American literature was world literature, also-that what we in the United States were exploring at that time as a native literary tradition that had much to teach us about our country also had much to say about Europe and the wide world beyond.

It has been my great fortune to have stellar guides on my scholarly path, and I accept the award of Doctor Honoris Causa from the University of Caen in the name of Michel Fabre, the great scholar of African American literature and one of the pioneers of European Black Studies. To President Le Querler and the Maison de la Recherche en Siences Humaines de Caen which championed my case, I extend my heartfelt thanks for the great honor which you bestow upon me today.

\section{AUTEUR}

\section{HENRY LOUIS GATES JR.}

Du Bois Institute, Harvard University 